\title{
Reason in Seventeenth-Century Millenarian England: The Example of John Milton's Paradise Lost
}

\author{
Kyriaki ASIATIDOU' (1)
}

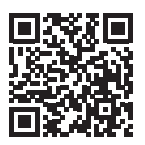

'Lecturer Dr., Gaziantep University, Faculty of Arts and Sciences, Western Languages and Literatures/English Language and Literature, Gaziantep, Turkey

ORCID: K.A. 0000-0002-2205-3192

\section{Corresponding author: \\ Kyriaki ASIATIDOU, \\ Gaziantep University, Faculty of Arts and Sciences, Western Languages and Literatures, English Language and Literature, Gaziantep, Turkey}

E-mail: kasiatidou@outlook.com

Submitted: 01.04.2021

Revision Requested: 15.07.2021

Last Revision Received: 23.07.2021

Accepted: 27.09.2021

Citation: Asiatidou, K. (2021). Reason in seventeenth-century millenarian england: The example of John Milton's Paradise Lost. Litera, 31(2), 491-523.

https://doi.org/10.26650/LITERA2021-907720

\begin{abstract}
Milton's England experiences military conflict, sociopolitical change, religious reform, and scientific progress. Seeking stability in a world of uncertainty, a substantial part of seventeenth-century English literature expresses millennial expectations, faith in the birth of a new and better humanity. Paradise Lost is a millenarian work that advocates humanity's perfection through the proper use of reason. The latter has as prerequisite man's self-knowledge-within a philosophical context-and union with God, Who is the supreme reason (Logos), within a religious context. Specifically, this article discusses Milton's definition of human reason and its implications for humanity's perception of reality/truth, through the examination of specific imageries reflecting four different levels of human reason in a hierarchical order: the lowest/first level, the low/second level, the high/third level, and the highest/fourth level. Imageries of sterility, erotic pervasion, ugliness, restrainment, concealment, sorrow, and power relationships mirror human reason in the first and second levels. Human reason in the first and second levels is corrupt and inadequate to perceive reality because it is based on the physical senses (natural reason). In contrast, imageries of fertility, erotic innocence, beauty, excess, revelation, bliss, and love relationships reflect human reason in the third and fourth levels. In the third and fourth levels, human reason incorporates love and creative imagination beyond the senses to endow humanity with a deep and comprehensive understanding of reality. The discussion of Milton's imageries of human reason and its redemptive function for humanity is mainly built on Christian philosophy.
\end{abstract}

Keywords: Milton, reason, Paradise Lost, millennialism, amillennialism 


\section{Introduction}

Political turmoil defines the seventeenth-century English society, with its most vivid expressions being the Civil war in the 1640s between the King, Charles I, and the Parliamentarian army, the beheading of Charles I, and Oliver Cromwell's protectorate in the 1650s. The Englishmen experience a transitory period defined by a tendency towards secular politics leading to the Restoration period in the second part of the seventeenth century and the early modern British state in the eighteenth century. The slowly formed and solidified middle class participates in the fight of the upper classes against absolute monarchy (the divine right of the King), asking for its active involvement in the country's finances and the making of laws (Brodey \& Malgaretti, 2002, pp. 73-4, 76). The seventeenth-century English demonstrations of sociopolitical change result from two collided kinds of religious secularism.

The first kind of religious secularism is related to the individual's resistance to the institution of religion, and consequently, to any man-made institution; the second kind of religious secularism is associated with the faith's rationalization and the perception of reality through physical observation (Ward, 2010, p. 74). In seventeenth-century England, the former finds expression in Puritanism and its repudiation of Laudianism, whereas the latter in the popularity of scientific observation and discoveries and the Christian faith's rationalization as expressed in the form of Latitudinarianism within the Anglican Church. Among notable Latitudinarian theologians who are contemporaries of Puritan Milton are John Tillotson, Simon Patrick, Edward Fowler, Joseph Glanvill, Edward Stillingfleet, and Gilbert Burnet (Kim, 2008, p. 130). The popularity of deism fueled Latitudinarianism. Milton's composing Paradise Lost (1667) coincides with Spinoza's publishing Tractatus Theologico-Politicus (1670). Just more than a decade after Milton's death, John Locke published An Essay Concerning Human Understanding (1689) and Reasonableness of Christianity (1695). Moreover, the translated full version of Spinoza's Tractatus Theologico-Politicus inspired English Deists, such as Matthew Tindal, John Toland, Charles Blount, Charles Gildon, and Anthony Collins, to form their political and religious views (Colie, 1959).

Also, numerous Millenarian works preceding Milton's Paradise Lost are published. Works, such as John or Henry Archer's "The personall reigne of christ upon earth" (1642), Samuel Gott's "Novae Solymae" (1648), Peter Chamberlen's "The Poore Mans Advocate" (1649), and John Eliot's "The Christian Commonwealth" (1659) (Sargent, 1989), propose 
the establishment of utopias that are inspired by the Christian eschatological expectations in various passages of the New Testament ${ }^{1}$. Paradise Lost attains the paradoxical identity of an amillennialist Millenarian work if it is read as an allegory. Amillennialism accepts the Second Parousia of Christ as a future historical event; yet, it stresses that time is relative and focuses on the millennium's allegorical interpretation as the period of "the kingdom of God" from the reception of the Holy Spirit by the Apostles and the establishment of the Christian Church to the Second Parousia of Christ, during which there will be one resurrection of the dead and the Divine plan for humanity's theosis will be complete:

From the very beginning of the Christian era there has been an eschatological tension between the present and the future, between the 'here and now' and the 'not yet.'The Church is living in two dimensions at once: the temporal and the eternal, the earthly and the heavenly, the militant and the triumphant, the historical and the eschatological. (Chamberas, 2004, p. x)

Milton shifts his readers' attention from the promised Second Coming of Christ as a physical event in the future to Christ's reign of the Church (the body of believers) at present by advocating that man's union with God is a mental action. The writer will attempt to support this argument by discussing the images of the four levels of human reason in Paradise Lost in this article.

Contemporary poets of Milton, including Francis Quarles, William Drummond, Richard Crawshaw, Thomas Traherne, George Herbert, and Henry Vaughan, reject the world of the senses, being "only in possession of a truer sanity, a farther vision" (Thompson, 1921, p. 176). They follow the Cambridge Platonists (i.e., Benjamin Whichcote, John Smith, Henry More, and Ralph Cudworth). The Cambridge Platonists adopt a moderate approach to reason by proposing the cooperation of (natural) reason and faith (intuition/ love connecting man with the divine realm) as the means to the Truth (ultimate reality /God) (Thompson, 1921). The Cambridge Platonists stress the immaterial and immortal

1 Matt. 24-25, Mrk. 13, Luk. 17, 1 Cor. 15, 2 Tim. 3, and 2 Pt. 3 speak of the Parousia (the second coming of Christ). Also, in his Apocalypse, St. John mentions the Millennial kingdom - the thousand-year earthly reign of Christ together with His martyrs, during which Satan is imprisoned in the abyss (Apoc. 20:1-6), released, defeated, and punished - the resurrection of the dead and the Final Judgement (Apoc. 20:7-15), and the new, perfected human society (the New Jerusalem) unites with God/Christ (Apoc. 21:1-8). 
essence of the human soul/mind, where Reason (Logos) resides². Referring to his reasoning towards an understanding of the concept of imago Dei present in biblical Genesis, Henry More explains:

\begin{abstract}
A Principle more noble and inward then Reason it self [...] I must confesse I received it neither from Man nor Angel. Nor came it to me by Divine Inspiration, unlesse you will be so wise as to call the seasonable suggestions of that Divine Life and Sense that vigorously resides in the Rational Spirit of free and well-meaning Christians, by the name of Inspiration. But such inspiration as this is no distractor from, but an accompisher and an enlarger of the humane faculties. (More, as cited in Dockrill, 1997, p. 63)
\end{abstract}

Henry More refers to the biblical story of man's creation because God created man in His image, endowing man with the divine gifts of reason (the faculty of perceiving the Truth) and free will (the right to use his reason to perceive the truth appropriately). Thus, Henry More contemplates the essence of human reason, rejecting that it is purely physical. He further denies that an external agent empowers human reason; an inner force, the Logos residing in one's soul, activates human reason. Logos is the divine reason (Christ), Whose attributes are speech, prime cause, creative imagination, and love (promise of union/covenant). [Note to the Reviewer:Till here this paragraph includes the writer's attempt to paraphrase and, to some degree, interpret More's words.] Dockrill notes that Philo, Clement, and Origen may be possible sources of More's definition of

2 Although the author's intention is to present an English perspective on the seventeenth-century intellectual spirit, Descartes's contribution to seventeenth-century philosophy centering on the concept of reason and its role to human perfection cannot be ignored. It is not certain whether Descartes had read Plato (Grene, 1999, p. 556), but he opposed the ancient skeptical tradition, particularly the skepticism of Pyrrho and Sextus, represented by Montaigne and Charron in the sixteenth and seventeenth centuries (Grene, 1999, pp. 554, 557). In his Meditations (1641), through the application of his hyperbolical doubt, Descartes refutes traditional skepticism and establishes "a new skeptical tradition"(Grene, 1999, pp. 553, 557). Traditional skepticism embraces a sense-based human reason. Because skeptics recognize the deceiving character of sense-perception, they accept the limitations of reason. Thus, they prefer to attain peace of mind through dealing with the world of appearances rather than the essence of things. In other words, Skeptics reject the epistemological aspect of sense and even more of the intellect (Grene, 1999, pp. 553, 558, 561). In opposition, Descartes rejects the epistemological character of sense-perception but argues for the epistemological character of human intellect. According to Descartes, when human reason is free from the sense, it is purified and can reach the innate truth through divine assistance (Grene, 1999, pp. 558, 563). The only similarity between practical skepticism (traditional skepticism) and Cartesian skepticism is that both are against Aristotelian dogmatism. Still, as it is show in Descartes's Meditations, they differ in aim. Whereas traditional Skepticism rejects all kinds of dogmatism, Descartes's anti-Aristotelianism targets Scholastic physics that rely on the Aristotelian principle that "nothing is in the intellect that has not been in sense" (Grene, 1999, p. 564-5). Descartes—an advocate of both natural and revealed Christian theology — wants to promote new physics based on human reason with metaphysical foundations (Grene, 1999, pp. 564-5, 571). 
imago Dei (Dockrill, 1997, p. 63). Also, Cheuk Yin Yam and Anthony Dupont argue that More's understanding of imago Dei is similar to Augustine's view on imago Dei expressed in De Trinitate XIV. Augustine relates human perfection (imago Dei) to the completion of human reasoning as a process of wisdom; thus, imago Dei is ontological and epistemological. Human reason is characterized by the relationship between remembering, understanding, loving oneself (self-knowledge) and remembering, understanding, and loving God (Yam \& Dupont, 2012, pp. 1-12).

Milton seems to adopt Cambridge Platonists'ontological and epistemological definition of reason dominant within the Church's body since her establishment. Milton associates humanity's deification with her capacity to perceive the Truth (the eternal and absolute reality). He reveals that human reason assisted by Logos (love and creative imagination) is the means to human perfection. In Monologion 13, Anselm of Canterbury notes, "All created things flourish and persist in their existence as long as they do, because they are sustained by what gave them that existence in the first place" (Anselm of Canterbury, 1076/2008, p. 25). Hence, human reason experiences the truth/reality through Logos. Reality exists in one's mind. The degree to which one can perceive reality relates to one's communion with Logos. In Monologion 47 and 48, Anselm of Canterbury states,

[...] The Son [Logos] is the understanding, knowledge, wisdom and truth of the paternal substance [the Father/God], so the Son is the understanding of understanding, the knowledge of knowledge, wisdom of wisdom and the truth of truth. [...] The supreme wisdom is undeniably conscious of itself. It would be most appropriate, therefore, to understand the Father in terms of consciousness and the son in terms of word. Words, after all, seem to be born from consciousness. (Anselm of Canterbury, 1076/2008, p. 59)

Reason manifests consciousness (the Son is a manifestation of the Father). Being the image of God, man's essence is his consciousness expressed through his reason; that is, one's reason reflects self-knowlege. In Monologion 66, Anselm of Canterbury observes, "The rational mind may be the only created thing that is able to rise to the task of investigating the supreme nature ... the efficacy of the mind's ascent to knowledge of the supreme nature is in direct proportion to the enthusiasm of its intent to learn about itself" (Anselm of Canterbury, 1076/2008, p.72). For Anselm of Canterbury selfknowledge is the only prerequisite to man's union with God. 
The Christian Milton, an active member of "the kingdom of God" on earth at present, advocates that reality extends beyond the physical boundaries of space and time; reality is mental and relative. Satan's statement, "The mind is its own place, and in itself/ Can make a heav'n of hell, a hell of heav'n" (PL, 1:252-255) (Milton, 1674/1993, p. 16) implies that hell and heaven are mental states rather than geographical places and that time addresses one's mind's present condition. Hell is associated with human reason in the first and second levels, the lowest and low mental states, in which man lacks self-knowledge and is disconnected from Logos. Heaven refers to the third and fourth levels of human reason, the high and highest mental states, in which man is in union with his soul and Logos (Asiatidou, 2020, p. 6).

This article discusses illustrations of the four levels/mental states in John Milton's Paradise Lost. All mental states are associated with the mental faculty of reason's improper or proper function, responsible for the human perception of reality. The first and second levels of human reason reflect an insufficient reason distorting reality. Therefore, they are illustrated through claustrophobic imageries of secrecy, physical ugliness, erotic perversion, destruction, sighs and woes, and power relationships. In the lowest mental state (the first level), man has a limited-and, thus, a distorted-perception of reality. The sovereign natural reason - that is, the exclusive use of the outer senses - blinds the human intellect. In the low mental state (the second level), man has a blurred, confusing perception of reality; the natural reason still prevails in the human mind, but glimpses of the truth occur sporadically. In contrast, imageries of abundance, excess, freshness, fertility, innocent eroticism, and beauty deliver the third and fourth levels, both of which represent productive reasoning. The high mental state (the third level) and the highest mental state (the fourth level) comprise the activation of divine reason in man, characterized by the harmonious collaboration of man's inner and outer senses. A man demonstrates faith in God's Logos, Who is love and creative force in both of them. In the third level (the high mental state), man's faith is manifested in man's love for God and the rejection of natural reason/self-love. In the fourth level (the highest mental state), man's faith is expressed through the exercise of his poetic genius. Through his love union with God and the use of his creative imagination, man becomes Christlike. He regains his ideal self and can perceive the eternal and absolute Truth, even within the physical reality's boundaries.

The discussion of the illustrations of human reason in all four levels in Paradise Lost is primarily supported by the words of Christian theologians of different denominations, including Athanasius of Alexandria, Augustine of Hippo, Anselm of Canterbury, Hildegard 
of Bingen, Francis of Assisi, Richard Rolle, Catherine of Siena, Theologia Germanica, Jacobus Arminius, Jacob Behmen, and Moise Amyraut. Their words may be read not only within a religious context but also in a philosophical context. Above its value as Christian and English literary work, Paradise Lost is characterized by spiritual universality and can be treated as a philosophical work. In "On Christian Philosophy: Una Vera Philosophia?" James F. Ross advocates that Christianity is a philosophy. As a school of thought, Christianity answers perennial and universal questions. Also, revealed knowledge is not an alien element to philosophy since the latter's neutrality has been challenged in the last decades. Furthermore, there is polyphony about various issues of faith within the Church body, and Christian wisdom can be contrasted to other religions, ethical systems, and folklores (Ross, 1992, pp. 356, 361). Under these conditions, Milton's Paradise Lost is a sample of Christian philosophy. It is Christian in its view on reason and reality but redeemed from sterile dogmatism and attempts to answer perennial and universal questions related to human essence and immortality.

\section{The Reality in the First Level and the Second Level of Human Reason}

In Paradise Lost, Satan, his fellow-fallen angels, and his offspring Sin and Death symbolize the fallen man's reason in the first and second levels, where there is no "true reason" (Duncan, 1957, p. 130). Satan's leading figure symbolizes man's ego-a "materialistic, disordered civilization" (Duncan, 1957, p. 129). Thus, man's love for his image causes man's detachment from God. Consequently, as Joseph E. Duncan notes, when man rejects"the all-comprehending, ordered hierarchy with God at the top, "he experiences a "psychological hell," similar to the hell of Satan, his fallen angels, Sin, and Death (Duncan, 1957, pp. 127, 130). Duncan continues, "In heaven the faithful accept God's will with love, carry it out with joy, and praise his wisdom with celestial harmonies" (Duncan, 1957, p. 130). In The City of God 5.19, Augustine of Hippo claims that the godly man owes all his virtues to God's grace. Thus, the godly man loves God and not himself: "[...] He [the virtuous man] strives earnestly to have their [his fellowmen's] praises directed to Him [God] from whom every one receives whatever in him is truly praiseworthy" (Augustine of Hippo, trans. 1871, p. 216). Anselm of Canterbury supports Augustine's teaching in Monologion 68, stating: "Its [the rational creature's] purpose is, in fact, to love the supreme essence and only to love other things for the sake of the supreme essence. This is because the supreme essence is good through itself, while everything else is only good through it" (Anselm of Canterbury, 1076/2008, p. 74). 
Satan's familiar rhetoric appeals to the readers' pathos (emotions) and logos (reason) because he personifies fallen humanity. Through the sound but deceiving rhetoric of Satan and the other angels, Milton attempts to awaken his Christian readers and see the illusion they consider their reality. Thus, Satan and his fallen angels become the mirror Milton places in front of himself and his readers. Milton considers knowing oneself-one's soul/one's essence-the step toward getting to know God (sanctification/ perfection). It seems that Milton portrays Satan very effectively because the poet himself, as a fallen man, shares the common man's tormenting thoughts that are related to his relationship with God and are rooted in humanity's fallen reason. In "Exteriority in Milton and Puritan Life Writing," Linda Tredennick observes that exercising the duty of the Puritan, Milton engages in systematic self-reflection and self-criticism both as "I" (the individual) and as "we" (a conscientious member of his community) (Tredennick, 2011, p. 160). Comparing Milton's works ${ }^{3}$ to several cases of seventeenth-century Puritan autobiographies_-such as Elizabeth White's The Experiences of God's Gracious Dealing with Mrs. Elizabeth White and John Bunyan's Grace Abounding to the Chief of SinnerTredennick notices that Milton views himself as a sinner who acknowledges that sanctification is a process during which he, the sinner, may relapse several times (Tredennick, 2011, p. 163). Thus, Milton has an "inferior self," which becomes a "Godinspired self" during the composition of Paradise Lost" (Tredennick, 2011, p. 167). Tredennick's argument that Milton's self-identity is unstable and in progress (Tredennick, 2011, pp. 166-7) strengthens this article's thesis that Milton perceives a multi-leveled human reason. Also, her observations justify the claim made later in this article that Milton adopts a tolerant attitude towards Satan. Milton deliberatively chooses to compare Satan to Hephaistus_an ambiguous figure in Greek mythology—because he views Satan as personifying the low mental state (human reason in the second level). In contrast, his degenerate descendants, Sin and Death, exemplify human reason in the first level (the lowest mental state).

Milton criticizes Satan, who is also called Diavolos (the Accuser), pointing out that the latter possesses all the vices for which he accuses God: "[...] The unconquerable will,/ And study of revenge, immortal hate,/ And courage never to submit or yield" (PL, 1:106-108) (Milton, 1674/1993, pp. 11-2) and "Left him at large to his own dark designs,/ [...] on himself/Treble confusion, wrath and vengeance poured" (PL, 1:213; 1:219-220)

3 Tredennick points out that although Milton has not written an autobiography, self-representations in his works are well-discussed in John S. Diekhoff's Milton on Himself: Milton's Utterances upon Himself and His Works (Tredennick, 2011, pp. 160-1, 176). 
(Milton, 1674/1993, pp. 14-5). Milton views God as the everflowing fountain of life from which all virtues emanate. Satan, a creation that has distanced himself from life out of his own free will, is condemned to a state of non-existence, death. Will/self-interest, hate, revenge, confusion, and wrath are negative feelings experienced only by a fallen mental state personified by Satan. Addressing his daughter Sin, Satan states, "There dwell and reign in bliss, thence on the earth Dominion exercise and in the air,/ Chiefly on man, sole lord of all declared,/ Him first make sure your thrall, and lastly kill./ [...] On your joint vigor/ My hold of this new kingdom all depends,/ Through Sin to Death exposed by my exploit" (PL, 10:399-407) (Milton, 1674/1993, p. 240).

Milton, the prophet-narrator, makes Satan draw a sincere and precise self-portrait:

To do aught good never will be our task,

But ever to do ill our sole delight,

As being the contrary to his high will

Whom we resist. If then his providence

Out of our evil seek to bring forth good,

Our labor must be to pervert that end,

And out of good still to find means of evil. (PL, 1:159-165) (Milton, $1674 / 1993$, p. 13)

And "[...] our better part remains/ To work in close design, by fraud or guile" (PL, 1:645-649) (Milton, 1674/1993, pp. 27-8), as well as "For I glory in the name, Antagonist of heav'n's Almighty King" (PL, 10:386-387) (Milton, 1674/1993, p. 240). In the low mental state, Satan seriously undermines his portrayal of God as an arbitrary ruler. Through his confession of being a destructive force that causes corruption through deception/ falsehood and his claim of being an enemy of God, Satan indirectly admits that God is a creative force and the Truth. In the excerpts above, Satan's words illustrate man's confusion in the low mental state (human reason in the second level). In the anonymous Theologia Germanica discovered and published in 1516 by Martin Luther, the soul of Christ the Divine has two eyes, which are also preserved during His historical existence. Through the inward right eye, the historical Christ's eternal essence connects with God and the realm of infinite bliss. Through the outward left eye, his material hypostasis connects with man's fallen nature, a state of unhappiness in the finite material world. The man, the image of God/Christ, perceives reality through the inward right or the outward left eye, depending on his mental state: 
Thus the inner man of Christ, according to the right eye of His soul, stood in the entire exercise of His divine nature, in perfect blessedness, joy and eternal peace. But the outward man and the left eye of Christ's soul, stood with Him in perfect suffering, in all tribulation, affliction and travail; [...] Now the created soul of man hath also two eyes. [...] But if the soul shall see with the right eye into eternity, then the left eye must close itself and refrain from working, and be as though it were dead. (Anonymous, trans. 1893, p. 20)

Milton's Satan (the man of natural reason) views a reality with two opposite eyes. The outward left eye defines reality based on self-love, and the inward right eye looks into the soul, the true self of man. Thus, whereas Satan acknowledges the domination of his death impulse expressed through deception and destruction, his ego-manifested in excessive pride, jealousy, and vanity-imprisons him into the claustrophobic physical reality, hell (Satan's kingdom).

Books 1 and 2 of Paradise Lost refer to Satan's and his fellow angels' response to their fall. Satan's tragic flaw is that he thinks that worshiping himself away from God in hell (physical reality as the product of his fallen mental state) is freedom:"[...] Here at last/ We shall be free; th'Almighty hath not built/ Here for his envy" (PL, 1:258-260) (Milton, $1674 / 1993$, p. 16). Satan's hell (physical reality) is perpetual mental slavery described by Milton as a claustrophobic environment: "[...] At last appear/ Hell bounds high reaching to the horrid roof,/ And thrice threefold the gates; three folds were brass,/ Three iron, three of adamantine rock,/ Impenetrable, impaled with circling fire,/ Yet unconsumed" (PL, 2:644-648) (Milton, 1674/1993, pp. 50-1). Hell's description appeals to the readers' physical senses. In contrast to the infinite divine realm, hell (physical reality) is a terrifying limited territory. Its limits that connote restrainment are inescapable. The difficulty of one's escape is stressed by the repetition of "thrice," "threefold," and "three." Matter (brass, iron, and adamant) makes up hell. The metals' harshness, toughness, and lack of colour connote complete deprivation of fertility, vitality, flexibility, and variety. Also, the high degree of the matter's opacity connotes obscurity. The unconsumed fire creates both a scary and suffocating atmosphere. In PL, 2:618-622, Milton provides another depiction of the claustrophobic hell that appeals to the readers' senses and emotions. The landscape of hell is dark, sterile, and concealing. Those present in the hostile and uninviting hell experience mental anxiety because everything existing there remains a mystery. Milton sees the mental states in the first and second levels as 
places where, no matter how hard man tries to reach the Truth through the physical reality's exploration, he never has access to the Truth. Therefore, he is always unhappy and hopeless.

Human reason's first and second levels are further depicted in Satan's guileful speech to Eve, and Adam's and Eve's perception of each other and their surrounding environment after eating from the Tree of Knowledge. These imageries are of lust, pain, sighs, and woes. Satan addresses Eve: "A goodly tree far distant to behold/ Loaden with fruit of fairest colors mixed,/ [...] To satisfy the sharp desire I had/ Of tasting those fair apples, I resolved/Not to defer; hunger and thirst at once,/ Powerful persuaders, quickened at the scent/ Of that alluring fruit, urged me so keen" (PL, 9:576-588) (Milton, 1674/1993, p. 213). In this excerpt, Satan symbolizes the man who perceives reality only through the employment of his outward left eye, viz., the exclusive use of the physical senses. The man who employs natural reason appears to succumb to his passions. The domination of one's passions reveals the lack of self-control and, consequently, his loss of freedom. Accordingly, the perception of a distorted reality resulting from the physical senses' sole employment reveals one's lack of self-knowledge (self-alienation). The domination of passions shaped by external stimuli reveals a lack of self-knowledge. Self-knowledge is the means to unrestrained spiritual freedom. Satan reverses the truth. He falsely identifies the unrestrained desire—lust for outer things— with freedom.

Man's employment of reason based on outer experience handicaps man's spirituality. When Milton associates different sciences that help humanity understand the Cosmosphilosophy, science, astrology, and astronomy - with Satan, they attain the negative connotations of concealment, deception, and falsehood. Some examples are in $P L, 10$ : 327-330, 411-414, 656-664, and 670-678. In contrast, when astrological and astronomical references occur within a verbal context related to the Divine, these knowledge fields assume the positive connotations of illumination/revelation. An example is in $P L$, 12:254-256. Milton claims that fields of human knowledge contribute only partially to man's attainment of the Truth. As products of man's ego, they cannot shed light on the mysteries of God because those who are away from God cannot know Him. Thus, a man should be cautious of the degree of reliance he shows to these means of knowing when getting to know the Truth/Reality.

The loss of freedom in hell also results from the secrecy and destructiveness exemplified by Sin's empowerment from her son's birth, Death (the death impulse in 
man). In $P L, 10: 243-251$, Sin falsely believes that her concealed "inseparable" union with Death will empower and set her free. The union of Sin and Death distorts the union between God and the human soul that grants the human soul spiritual immortality. Through the secretive and deceiving union of Sin and Death, Milton talks about man's futile optimism in the low mental state (human reason in the second level). The man of natural reason has the illusion - which is never illuminating - that he will have access to knowledge that can endow him with unrestrained authority by distancing himself from God.

Sin's rhetoric sounds strikingly familiar to the readers who have already been exposed to Eve's rhetoric. After tasting the forbidden fruit, the deceived Eve says, "Experience, next to thee I owe,/ Best guide; not following thee, I had remained/In ignorance, thou open'st wisdom's way,/ And giv'st access, though secret she retire./ And I perhaps am secret" (PL, 9:807-811) (Milton, 1674/1993, p. 219). Tragic irony permeates Eve's excitement caused by her thought that her wisdom attained through her disobedience can be kept "secret" / private. Within a Christian context, everything private connotes selfhood/self-interest, and, thus, it is condemned ${ }^{4}$. Milton's Christian audience knows that Eve's secret/private knowledge does not enlighten her but traps her in a state of ignorance and confusion.

Similar to the meaning of "secret" is the meaning of "hid" and "hide." Adam says, "I heard thee in the garden, and of thy voice/ Afraid, being naked, hid myself" (PL, 10:116117) (Milton, 1674/1993, p. 233) and "[...] Hide me from the face/Of God, whom to behold was then my highth/ Of happiness ( $P L, 10: 723-725$ ) (Milton, 1674/1993, p. 249). Because Adam feels guilt produced by his ego (Diavolos/Satan the Accuser), he wants to conceal his nakedness. Adam's concealed nakedness may be interpreted in two different ways; yet, both interpretations speak about the state of non-existence that a creature experiences distancing himself from God. According to the first interpretation, if Adam's nakedness connotes exposure/lucidity, his will to conceal himself reveals his will to suppress the Truth, his ideal self. According to the second interpretation, Adam's nakedness connotes sterility/nothingness and should be associated with his distancing from God; Adam desperately attempts to conceal his nothingness because he feels

4 The association of secrecy and concealment with man's mental fall (committing hubris and experiencing hatei) is also discussed in Greek tragedy. In Sophocles's King Oedipus, Oedipus's distorted perception of reality-and consequently his suffering and fall-results from the secrets of his immediate environment, including himself. His parents King Laius and Queen Jocasta concealed the secret of his birth, his foster parents, King Polybus and Queen Merope, never confessed his adoption, Laius's shepherd and servant intentionally misinformed the Thebans about the number of Laius's killers and the way he died, and Oedipus never informed the Thebans he had killed a person (Sophocles, ca. 429 B. C. E./ trans. 1974). 
shame. His shame, a negative feeling, results from the misperception of his relationship with God as a power relationship. In "The Genesis of Gender Transgression," Lori Hope Lefkovitz points out that "[Adam's] nakedness is the sign of both innocence and guilt" (Lefkovitz, 2001, p. 409). Adam's nakedness is the condition of innocence and truth. In contrast, his self-consciousness - feeling guilt for his disobedience and shame for his bodily nakedness-distorts his logic and causes the reversal of the truth (Lefkovitz, 2011, p. 409). Thus, Adam's self-concealment becomes synonymous with his "selfrevelation, revelatory of $\sin ^{\prime \prime}$ (Lefkovitz, 2011, pp. 408-9). Moreover, the biblical story of Adam's first disobedience is associated with the human construct of gender and introduces the "identity concealment and masquerade" that the individual must accept upon entering our culture ( Lefkovitz, 2011, pp. 409-10). This culture is "a two-sex system, the nuclear family, patriarchy and matriarchy, seducers and victims, and many familiar details of gendered social organization" (Lefkovitz, 2011, p. 409). In other words, Lefkovitz claims Adam's concealment symbolizes our fallen human society characterized by division/fragmentation and power relationships.

Like human reason in the first level is mirrored in Adam's first moment of realizing his nakedness, it is also reflected in the sensual, dark, and aggressive erotic union of Adam and Eve immediately after their fall: "[...] That false fruit/Far other operation first displayed,/ Carnal desire inflaming, he on Eve/ Began to cast lascivious eyes, she him/ As wantonly repaid; in lust they burn" (PL, 9: 1011-1015) (Milton, 1674/1993, p. 224). Milton is influenced by the marriage imagery of various biblical passages referring to the union between Christ and the believer (or the Church), including Matthew 25:1-13, John 3:29, 2 Corinthians 11:2, Ephesians 5:31-32, and Revelation 21.2, 9-10, and 22:17. Thus, he rejects erotic unions rooted in self-love. Such false relationships symbolize the domination of ego/natural reason in one's soul and the soul's detachment from the Holy Spirit in man, Who is love.

Likewise, in human reason's second level, Adam and Eve experience their surrounding environment in the radically opposite way to the peaceful, loving, and orderly way they perceive it through their innocence in their prelapsarian state (human reason's third level):

\section{[...] Discord first}

Daughter of Sin, among th' irrational,

Death introduced through fierce antipathy: 
Beast now with beast gan war, and fowl with fowl,

[...] With countenance grim

Glared on him passing: these were from without

The growing miseries. ( $P L, 10: 707-715)$ (Milton, 1674/1993, p. 249)

The above excerpt also relates to Adam's words to Eve- "The only sign of our obedience left/ [...] Dominion giv'n/ Over all other creatures that possess/ Earth, air, and sea" (PL, 4: 428-432) (Milton, 1674/1993, p. 97) —and Eve's words to Satan —“"...] We live/ Law to ourselves, our reason is our law" (PL, 9: 653-654) (Milton, 1674/1993, p. 215). Before their mental fall, Adam and Eve (humanity) control nature as a physical manifestation of their faith in Logos. Humanity's faith is their mirror-response to Christ, Who is Love and the Covenant/Law (Logos). Thus, the love union between a man and Christ also becomes the Law. A Christian interpretation of the above passages does not identify the Law with Jehovah and the Old Testament (the Covenant of Works). According to the Trinity doctrine, the Law/Covenant is Christ/Reason/Logos, the infinite and eternal God. Losing faith in God, man perceives reality only with his outer senses, and, thus, he loses control over nature, which now becomes alien to man.

A hostile nature that also raises the issue of mortality for man provokes the latter's psychological turmoil. Man's emotional misery that becomes excessive in the lowest mental state is expressed in various passages of Paradise Lost, including Adam's exclaiming, "O fleeting joys/ Of Paradise, dear bought with lasting woes!" (PL, 10:741742) (Milton, 1674/1993, p. 250) and "Why hast thou [God] added/The sense of endless woes?" (PL, 10:753-754) (Milton, 1674/1993, p. 250). The lowest mental state's climax occurs when Adam and Eve (humanity) reject their soul and the life force/divine reason that resides in her. Adam, permeated by despair, exclaims, "Why comes not Death,/ [...] With one thrice-acceptable stroke/ To end me?" (PL, 10:854-856) (Milton, 1674/1993, p. 252). The imagery of woes and death contrasts the fertile erotic union between Christ and the human soul through the two parties' collaborative activation of divine reason in man. Similarly, a mournful Eve advises Adam, "[...] In thy power/ It lies, yet ere conception to prevent/ The race unblest, to being yet unbegot./ Childless thou art, childless remain; so Death/Shall be deceived his glut, and with us two / Be forced to satisfy his rav'nous maw" (PL, 10:986-991) (Milton, 1674/1993, p. 256).

Adam's consent to Eve's suggestion to divide their work's load so that their physical tasks will not be interrupted by their frequent discussion causes their fall. Division 
defines the world of the man of natural reason, as opposed to the unity of the world perceived by the man in his pristine state, in union with Logos. Irony characterizes the rhetoric of the initial reaction of Adam, who reminds Eve, "For not to irksome toil, but to delight/ He [God] made us, and delight to reason joined" (PL, 9:242-243) (Milton, $1674 / 1993$, p. 204). Reality is mental, not physical. Thus, Milton believes that only through reason does man experience ultimate pleasure. The key phrase "to reason joined" has two complementary meanings, depending upon the grammatical function of "reason" as a verb or a noun. If "to reason" is read as an infinitive, Adam refers to the union of pleasure between an individual (Adam) and his soul (Eve). Adam points out that "to reason" - the means to one's happiness - an individual should get to know ("joined") his soul. If "reason" functions as a noun, it refers to the union of pleasure between a man and God (the eternal and infinite reality) through the activation of Logos (reason) in man. The connection of man and his soul is a prerequisite to man's good reasoning, the bond between him and God. "Delight to reason joined" is the imagery of innocent eroticism (marriage) produced by the words "delight" and "joined" that imply two main attributes of the divine reason (Logos), and, subsequently, of man's pure reason: love and speech (communication/deliberative discourse).

Milton also describes the lowest and the low mental states through power relationships that define physical reality, as opposed to the love relationship that defines the supranatural reality experienced only by the man in the high and the highest mental states. In Paradise Lost, employing Satan's language, Milton, the prophet-narrator, refutes Satan's rhetoric that ornaments his claim of God being an arbitrary oppressive ruler. Milton calls Satan a "sovran" (PL, 1:246) (Milton, 1674/1993, p. 15), "great Sultan" (PL, 1:348) (Milton, 1674/1993, p. 18), "great emperor" (PL, 1:378) (Milton, 1674/1993, p. 19), and "sovran power" (PL, 1:753) (Milton, 1674/1993, p. 31). Milton alludes to Christianity's external enemies' attempts of invading Europe and Christianity's internal threat exemplified by European political authorities who promote the collaboration of the state and the Church and, thus, contribute to the corruption of prelates. In OfReformation in England, Milton accuses Emperor Constantine (A.D. 306-337) as the initiator of Christianity's corruption. During Constantine's time, the bishops appear "dressed in the gaudy allurements of a whore" (Milton, 1641/1847, p. 11). According to Milton, "At this time Antichrist began to put forth his horn, and that saying was common, that former times had wooden chalices and golden priests; but they, golden chalices and wooden priests" (Milton, 1641/1847, p. 11). Milton may also allude to the Crusades, Christians' holy war for the recovery of Jerusalem. The Catholic council of Clermont in 1095, under 
Pope Urban II's leadership, initiated the crusades. Christian European kings were attracted to the Church's idea of the remission of sins through participation in the Crusades because it justified their want for lands (Black, 2002, p. 55).

Besides the above imageries of sterility, concealment, and division, Milton creates imageries of an incapacitated reason in the first and second levels through bodily deformity and ugliness. Satan, the architect of Pandemonium, resembles Hephaistus, the architect of the Olympian palace. In Iliad's Rapsody A, Homer uses the epithet "illustrious artist" (line 704) to address Hephaistus (Homer, trans. 1791, p. 12) and refers to the "brazen-floor'd abode" (line 527) of Zeus made by Hephaestus (Homer, trans. 1791, p. 10). In "The Image of the Tower in Paradise Lost," Anthony Low explains that the Fathers of the Church-including Eusebius Pamphili, St. Justin Martyr, and St. Jerome-view the tower, such as Pandemonium (PL, 1:710-730) (Milton, 1674/1993, pp. 29-30), as a flawed human imitation of the power, wealth, and beauty of God's kingdom (Low, 1970, p. 175). In Christian writings, the tower becomes the archetypal image of human ambition, pride, and temporality, and its upward (rise) and downward movement (fall) is associated with the period between Adam and New Adam/ Christ and restored humanity (Low, 1970, pp. 171-4). After describing the erection of Pandemonium, the illusion of perfection and perenniality through the unification of eastern and western aesthetics, Milton repeats the word 'tower' in the imagery of Hephaistus's fall, continuing, thus, to talk about the fall of Satan from the highest level (heaven) to the lowest level (hell) of reason (175-6). Milton, the prophet-narrator, states, "Men called him Mulciber; and how he fell/ From heav'n, they fabled, thrown by angry Jove/ [...] Dropt from the zenith, like a falling star,/ On Lemnos, th' Aegean isle. Thus they relate,/ Erring" (PL, 1:740-741, 745-747) (Milton, 1674/1993, pp. 30-1). Milton alludes to lliad's Rapsody A's last scene, in which Hephaistus becomes a mediator in the verbal conflict between Zeus and Hera: "Who can resist the Thunderer?/ Me, when once /I flew to save thee, by the foot he seized/ And hurl'd me through the portal of the skies" (lines 727-729) (Homer, trans. 1791, p. 13). Hephaistus refers to his being thrown from Olympus by the enraged Zeus when he supported his mother, Hera, during one of the couple's past argumentations (Grant \& Hazel, 2006, p. 158.) Focusing on Milton's utterance "[...]Thus they relate,/ Erring" (PL, 1:746-747) (Milton, 1674/1993, p. 31), Jonathan H. Collett claims that Milton does not question the authenticity of this version of the myth but the chronology of the events making up Hephaistus's narration (Collett, 2011, p. 92). Hephaistus distorts reality because of his selective memory. According to the myth as narrated by Hesiod, his mother, Hera, first throws Hephaistus from Olympus because 
she cannot stand her offspring's spectacle, who has a lame leg (Kerenyi, 2002, pp. 1501). Milton compares the half-true narration of Hephaistus to Satan's creating an illusionary reality by describing God as an angry punisher who resembles Zeus. Like Hephaistus, Satan has selective memory by referring to the Old Testament's God, the Punisher, not the God of the New Testament, Who is love. Satan's perception of God is limited, and thus, false.

Still, beyond the allusion to the specific mythological story, Milton's comparison of Satan to Hephaistus proves that Milton demonstrates tolerance toward the man of the natural reason. In Plato's Symposium, Hephaistus plays a positive role in Aristophanes's speech on love. Like Aristophanes, Milton believes in love as a transformative power towards man's deification (regaining his ideal self). A man's (mental) deformity in the first and second levels is emendable if the man has the will to rise intellectually and enter the third level of the love union between the human soul and divine reason/ Logos. According to Aristophanes's narration, the original sexes' fragmentation has resulted from their excessive pride/ego channeled into their falsely aspired usurpation of the heavenly throne. Aristophanes refers to Hephaistus, the god who can help the sexes regain their prelapsarian state. Hephaistus is the god who can reunite the two halves of each of the three fragmented sexes: "'Do you desire to be wholly one; [...] for if this is what you desire, I am ready to melt you into one and let you grow together, so that being two you shall become one, [...] I ask whether this is what you lovingly desire, and whether you are satisfied to attain this?"' (Plato, trans. 1892, p. 192). Aristophanes continues his speech, pointing out,

There is not a man of them who when he heard the proposal would deny or would not acknowledge that this meeting and melting into one another [...] was the very expression of his ancient need. [...] Wherefore let us exhort all men to piety, that we may avoid evil, and obtain the good, of which love is to us the lord and minister. (Plato, trans. 1892, pp. 192-3)

Aristophanes argues for man's natural inclination to union with God through the activation of divine reason/love in him (the life impulse). In all aspects, through Hephaistus's association with bodily deformity, Milton communicates Satan's deformity/ ugliness and God's beauty. Satan's falsehood (the impartial perception of reality) and destructiveness oppose the eternal and infinite divine truth/reality. 
Satan's offspring, Sin and Death, natural reason's/ego's products, inherit his ugliness. Their monstrous appearance reveals the increasing destructiveness and horror of man's prolonged detachment from his soul, where divine reason resides, and, thus, from God. Satan, the symbol of ego and natural reason, represents both the first and second levels, whereas his offspring are fixed symbols of the first level. In $P L$, 2:650-656, the upper part of Sin's body is luring but deceiving, and her lower part, where her reproductive organs are located, is grotesque and sterile. In PL, 2:747-758, Milton's readers learn that Sin has sprung out of her father's head as the growing seed of his "bold conspiracy" (PL, 2:751) (Milton, 1674/1993, p. 53) against God. Her birth alludes to Athena's springing out of Zeus. Satan and Sin appear here as poor imitations of Zeus and Athena. Zeus, the father of gods and men, resembles God the Father, and Athena, the goddess of wisdom, resembles Christ the son/the Logos and the Holy Spirit (the Logos in man). According to Hildegard of Bingen's theology of the feminine, Christ (the Son/the Incarnate Word) and the Holy Spirit (the Word residing in the human soul) are Sapientia (Reason/Wisdom/Creative Imagination) and Caritas (Love), the feminine side of God/ the Father (Newman, 1997, pp. 36, 43-44, 46-47, 49). Satan (ego/natural reason) is a false god, and his daughter Sin is a false goddess. Sin is the product of Satan's committing hatei (blindness of the intellect); that is, sin appears as the falsehood that emanates from the distorted mind/nous.

Death's deformity—described in $P L, 2: 666-669$-is devastating. Death lacks form and thus represents chaos/disorder. Death does not have existence; it is nothing. The man who sees reality based on the physical senses (natural reason) experiences only the finite physical reality of corruption and death, denying the life force of divine reason in him. Consequently, he alienates himself from his soul/higher self, the means of his union with God/Christ, through which he attains spiritual immortality. Death is the offspring of the incestuous relationship of Satan and his daughter Sin. Milton describes their union:"[...] With attractive graces won/The most averse, thee chiefly, who full oft/Thyself in me thy perfect image viewing/ Becam'st enamored, and such joy thou took'st/With me in secret, that my womb conceived/A growing burden" (PL, 2:762-767) (Milton, 1674/1993, pp. 53-54). Sin reveals that she is self-love Collett, 2011, p. 91). Sin's relationship with Satan is the distorted version of the human soul's intimate relationship with God's Logos, Who is Love, the former being the latter's image. Unlike the innocence that characterizes the erotic union of man's soul and Christ/divine reason in the third level and the fourth level, the intimate relationship of Sin and Satan is characterized by obscurity and restrainment, which comprise the "shadowy" essence of death (human reason in the first level). 


\section{The Reality in the Third Level and the Fourth Level of Human Reason}

In Hebrew, Beulah, used in Isaiah: 62:4 denoting the land of Israel, means marriage. Thus, imageries of fertility and abundance deliver the third mental state, where natural reason is invigorated through its union with the Holy Spirit. In Paradise Lost, the high mental state is depicted as Eden's garden, a place surpassing all renowned mythological lands in abundance, fertility, freshness, and beauty. The garden of Eden mirrors the immense creativity of the virile Christian God (the Holy Trinity). The high mental state's vivid imageries as a pastoral setting are in $P L, 4: 131-153,4: 216-287$, 7:309-337, 7:449-456, and 7:501-502. Also, there are strong ties between Eve and nature, defined by fertility, eroticism, and excess as signs of creativity. In $P L$, 5:331344, Eve's free and innovating blending of various tastes aims at pleasure through the full use of what fertile mother earth produces. Eve's virtue of creativity has nothing to do with an unravished body literally. In $P L$, 5:388-391 compliments 5:331-344; it appraises fertile Eve by angel Raphael, representing the infinite and eternal world (ultimate reality).

Still, the most profound imagery of the high mental state is humanity's godlike presence in the garden of Eden:

Two of far nobler shape erect and tall, God-like erect, with native honor clad In naked majesty seemed lords of all, And worthy seemed, for in their looks divine The image of their glorious Maker shone, Truth, wisdom, sanctitude, severe and pure, Severe but in true filial freedom placed. (PL, 4:288-294) (Milton, 1674/1993, p. 93)

The imagery of the harmonious and stable monogamous marriage of two equally virtuous partners delivers a perfect man in communion with his inner self. The symmetry and order of the physical appearance of the couple-"nobler shape erect and tall"corresponds to the virtuous character of the man, who is the image of God ("God-like 
erect" $)^{5}$. To avoid the exclusive literal interpretation of the couple's physical perfection, Milton associates the couple's simple and transparent "naked majesty" with the divine attributes, "Truth, wisdom, sanctitude, severe and pure."The relationship between Adam and Eve implies three different unions. The original union of the two natures of Christ (fully God and fully man), the Redeemer of humanity, who plants in humanity the seed of immortality, the union between a man and his soul, and the union between the human soul, the feminine side of man, and Christ, the male lover.

Milton strengthens the union's imagery (the pristine mental state of humanity) by

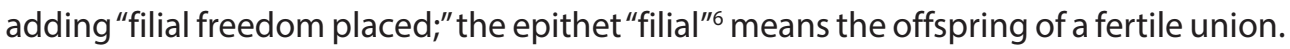
The word "filial" implies Logos (Christ), Who is divine reason. Logos is the Son of God and the Son of Man, epithets revealing His dual nature. The affinity of Christ to both God and humanity is brought forth. Becoming Christlike through the activation of divine reason in his heart, the fallen man can perceive the ultimate reality in the higher mental states. Also, Milton's reference to "freedom" reveals the vital role of reasoning towards man's attainment of the Truth. Choice (free will) implies the prior exercise of reasoning, and the proper function of reason depends on the degree of the individual's connection to his soul (the individual's mental state).

In Paradise Lost, Milton refers to the death impulse (natural reason) as a threatening force coexisting with the life impulse (divine reason) in Adam's soul. Milton highlights the human capacity to preserve his existence within the ultimate reality through the deliberative activation of divine reason in him: "[...] within himself/ The danger lies, yet lies within his power:/ Against his will he can receive no harm./ But God left free the will, for what obeys Reason, is free" (PL, 9:348-352) (Milton, 1674/1993, p. 207). Milton seems to follow the Christian tradition in his attempt to define free will. Free is the man who controls himself-that is, he is characterized by self-knowledge and preserves his pure reason intact. In On the Incarnation of the Word (1.3), Athanasius of

5 Imageries appealing to the human senses are frequent in Christian literature because as Athanasius of Alexandria notes, "When, then, the minds of men had fallen finally to the level of sensible things, the Word submitted to appear in a body, in order that $\mathrm{He}$, as Man, might center their senses on Himself, and convince them through His human acts that He Himself is not man only but also God, the Word and Wisdom of the true God. (On the Incarnation of the Word 3.16) and "The Greek philosophers say that the universe is a great body, and they say truly, for we perceive the universe and its parts with our senses. But if the Word of God is in the universe, which is a body, and has entered into it in its every part, what is there surprising or unfitting in our saying that He has entered also into human nature?" (On the Incarnation of the Word 7.41).

6 God the Father addresses His Son-Who is the Word (Logos) and Who, later, becomes the Incarnate Word/ Christ—within a spirit of collectiveness: "Let us make now in our image, man/ In our similitude" (PL, 7:519520) (Milton, 1674/1993, p. 177). 
Alexandria states that in the high mental state (human reason in the third level), man is the image of God, having "a share in the reasonable being of the very Word Himself" and endowed with free will to preserve his blessed status. According to Athanasius of Alexandria, "the will of man could turn either way" based on the prevalence of natural or pure reason. Athanasius's view on human free will may not be understood as a choice between sinning and not sinning. He avoids using the epithet "free" when he associates human will with choice. Instead, using "turning either way," Athanasius speaks of the two opposites states of sin and freedom that are caused by the domination of physical reason (death) and divine reason (life) in the human soul, respectively. Athanasius claims that human will is free only when the human soul is connected to Logos. Only the mind whose reason is fully activated can experience perfect freedom, eternal and infinite life.

Athanasius's view on free will is a popular one among Christian theologians. In the Dialogues on the Supersensual Life, Jacob Behmen foregrounds man's responsibility for his experiencing the yoke of ego (human reason in the first and second levels):

In as much as in thine own seeing thou dost see in thine own willing only, and with thine own understanding thou dost understand but in and according to thine own willing, as the same stands divided from the Divine Will. [...] It keeps thee in thine own dark prison which thou makest for thyself, so that thou canst not go out thence, or come to that state which is Supernatural and Supersensual. (Behmen, 1901, p. 16)

On Free Will, Anselm of Canterbury restates Athanasius in his words,

When they [the apostate angel and the first man] had a free will that could not be coerced by anything else, they willingly and without necessity sinned. They sinned through their own free will, though not insofar as it was free, that is, not through that thanks to which it was free and had the power not to sin or to serve sin, but rather by the power it had of sinning, unaided by its freedom not to sin or to be coerced into the servitude of sin. (Anselm of Canterbury, trans. 2008, p. 177)

Similarly, in Milton's age, man's capacity to freely employ divine reason in him aiming at his perfection finds expression in Jacobus Arminius's (1560-1609) and Moise Amyraut's 
(1596-1664) theologies. According to Arminius, divine grace is sufficient (gratia sufficiens) but not efficacious (gratia efficax). God's grace is given equally to all and is redeeming, but the man should practise his free will to respond to it to be saved (Myers, 2004, pp. 79-80). Amyraut believes that although our reason is corrupted, God has granted man an intellectual inclination towards the true and the good. Man's illumined reason cures his will that transforms into faith (Myers, 2004, pp. 85-7). Arminius and Amyraut relate free will to an active human reason, a complete human reason in union with Logos. They view sinning as the product of passive reason, an incomplete reason based on the physical senses.

Throughout Paradise Lost, various passages reveal the nature of Adam's and Eve's love relationship (human reason in the third level). Milton does not associate the sexual act with humanity's fall. In PL, 2:345-351 and 7:131-161, Augustine of Hippo's teachings ${ }^{7}$ inspire Milton to talk about the human mind's fertility (the high mental state and the highest mental state): Adam and Eve would have procreated to fill the empty heaven after Satan's and his legion's fall even if they preserved their prelapsarian state. Augustine of Hippo praises marital love and sexuality for refuting the Manicheans by pointing out that the main attributes of marriage - "its exclusiveness, its procreativity, and the unbreakable nature of the conjugal bond" - reflect humanity's inner yearning for God (Burke, 2012, p. 381). Human procreation as an act of faithful love corresponds to the activation of divine love and creativity (Logos) in man through which he participates in the eternal and infinite reality.

Other passages related to Adam's and Eve's union are in Book 4. Milton, the poetprophet, states:

\section{[...] Though both}

Not equal, as their sex not equal seemed;

For contemplation he and valor formed,

For softness she and sweet attractive grace,

He for God only, she for God in him:

His fair large front and eye sublime declared

Absolute rule. ( $P L, 4: 295-301$ ) (Milton, 1674/1993, p. 93)

7 Hildegard of Bingen, whose teachings on the Second Eve are presented in the discussion of the highest mental state later in this article, is another Christian figure that disassociates sexual love from humanity's sin and guilt (Newman, 1997, p. 103). 
And Eve affirms her servitude toward Adam, saying: "O thou for whom/ And from whom I was formed flesh of thy flesh,/ And without whom am to no end, my guide/ And head (PL, 4:440-443) (Milton, 1674/1993, p. 97). Milton criticizes the embracers of the deceiving physical reality and opposes master narratives built upon power relationships. His analogical patriarchal language delivers the paradoxical nature of Christianity. Adam symbolizes each individual and humanity as a whole. Eve symbolizes the soul of each person - and the soul of humanity as a whole — that unites with Christ.

The symbolic use of Adam, the male, as God's image is associated with man's seed, mirroring the virility/fertility of God/Christ, Who is life and creative force. The symbolic use of the woman as the vessel of man's spiritual life is associated with her role as carrier and materializer of life through the bearing of offspring. The symbolic use of the woman as the vessel of man's spiritual life celebrates humanity's feminine aspect, an image of God's feminine side, Christ. Eve's (the human soul's) submission, obedience, and humility are also Christ's virtues. He is the eternal, infinite, and one God, Who assumes a fully human nature to live as a man and suffer as the faithful servant of humanity (theology of the Cross). Therefore, the human soul's (Eve's) demonstration of servitude permeated by pure love towards God, Who is Love, is the feature of humanity in the high mental state and the highest mental state. Being created according to His image, Adam and Eve (humanity) reflect the masculine and feminine attributes of Christ (the Logos of God) $)^{\text {. }}$

Also, addressing Adam, Raphael explains:

\section{[...]'He formed thee, Adam, thee O man}

Dust of the ground, and in thy nostrils breathed

The breath of life; in his own image he

Created thee, in the image of God

Express, and thou becam'st a living soul.

Male he created thee, but thy consort

Female for race. (PL, 7:524-530) (Milton, 1674/1993, p. 177)

8 "Although logos is primarily a masculine noun, its multiple meanings are expressed by both masculine and feminine nouns, including aitia/cause (feminine noun) connoting nous/mind (masculine noun) and sophia/ wisdom (feminine noun), logos/speech (masculine noun), and diathiki/covenant (feminine noun) connoting charis/grace (femine noun), agape/love (feminine noun), and Eros/love (masculine). [...] Christ as Logos (masculine noun) is the true life/zoe (feminine noun); He is the essence/ousia (feminine noun) and the divine will/energia (feminine noun)" (Asiatidou, 2020, p. 9) 
And when Adam confesses his admiration for Eve, Raphael advises him in a reprimanding tone:

Greatness of mind and nobleness their seat

Build in her loveliest, and create an awe

About her, as a guard angelic placed

[...]

[...] Fair no doubt, and worthy well

Thy cherishing, thy honoring, and thy love,

Not thy subjection (PL, 8:557-559, 568-570) (Milton, 1674/1993, p. 195).

When Raphael advises Adam not to worship Eve (Adam's soul), he refers to man's self-worship as an obstacle to man's spiritual advancement that solely depends on the activation of divine reason in man. Raphael refers to man's false submission to- what William Blake calls - the female will. When a man views his soul as separate from him, the alienated soul becomes the female will. The female will is self-love/ego and the domination of natural reason, which becomes the basis of man's worship of nature/ the physical environment and his embracement of falsehood, a finite physical reality (Damon, 1988, pp. 120-1). Moreover, the concepts of submission, obedience, and humility have negative connotations within a secular world built on power relationships. However, in Paradise Lost, they are viewed as active believer's virtues. That is, he voluntarily demonstrates passivity and surrenders his ego/natural reason (self-love) to divine love/ reason, proceeding, thus, to union with God.

Adam's and Eve's intimate relationship before and after their fall reflects the faithfulness, commitment, and good communication which must characterize the relationship of Adam/husband (the man) and Eve/wife (man's soul) as a prerequisite in the process of humanity's contemplation of the Divine. The imageries of Adam's and Eve's union of pleasure echo the believer's erotic desire for the divine reason and function as allegories of humanity committed to its soul, viz., humanity who knows its true self. Milton, the poet-prophet, admires the "fair couple, linked in happy nuptial league" (PL, 4:339) (Milton, 1674/1993, p. 95) and states, "[...] hand in hand they passed, the loveliest pair/That ever since in love's embraces met,/Adam the goodliest man of men since born/His sons, the fairest of her daughters Eve." (PL, 4:321-324) (Milton, 1674/1993, p. 94). 
With "matrimonial love" (PL, 9:319) (Milton, 1674/1993, p. 206), Adam confesses to Eve, "I from the influence of thy looks receive/ access in every virtue, in thy sight/ More wise, more watchful, stronger, if need were/ of outward strength ( $P L, 9: 309-312$ ) (Milton, 1674/1993, p. 206). Milton highlights the role of a man's soul as his spiritual guide. The believer (Adam) looks inwardly (into his soul) for self-knowledge, which, in turn, gives him access to getting to know God. Another example is Michael's addressing Eve, "Lament not Eve, but patiently resign/ What justly thou hast lost; nor set thy heart,/ Thus over-fond, on that which is not thine;/ Thy going is not lonely, with thee goes/Thy husband, him to follow thou art bound" (PL, 11:287-291) (Milton, 1674/1993, p. 267). The harmonious cooperation of man's faculties-sense, affection, imagination, and reason - that characterizes the function of divine reason in man is also implied through Michael's advice to Eve/man's soul not to be overwhelmed by the affections.

Eve is an integral part of Adam's existence. Adam confesses,

Should God create another Eve, and I

Another rib afford, yet loss of thee

Would never from my heart; no no, I feel

The link of nature draw me: flesh of flesh,

Bone of my bone thou art, and from thy state

Mine never shall parted, bliss or woe. (PL, 9:911-916) (Milton, 1674/1993, p. 222)

and "[...] If death/ Consort with thee, death is to me as life;/ So forcible within my heart I feel/ The bond of nature draw me to my own,/ My own in thee, for what thou art is mine;/ Our state cannot be severed, we are one,/ One flesh; to lose thee were to lose myself" (PL, 9:953-959) (Milton, 1674/1993, p. 223). Milton endows Eve with a rich symbolism centering on the concept of life. Eve symbolizes both the body and the soul of man, that is, man's dual nature. Eve is made of flesh and is the mother of humanity. Thus, Eve is a symbol of man's material hypostasis. However, she is also man's feminine portion (the human soul) in which the divine life force resides. That is, Eve is the spiritual essence of man. Adam acknowledges this truth by admitting that his attraction to Eve/ Life is innate; she is both his hypostasis (body) and his ousia (soul).

In Book 12, Milton makes Eve address Adam rephrasing his words, "But now lead on;/ In me is no delay; with thee to go,/ Is to stay here; without thee here to stay,/ 
Is to go hence unwilling; thou to me/ Art all things under heav'n, all places thou,/ who for my wilful crime art banished hence" (PL, 12:614-619) (Milton, 1674/1993, p. 300). Eve voluntarily submits herself to Adam, realizing that her union with him is her ideal state of being and acknowledging that her detachment from him would cause his fall. Milton stresses the necessary union between a man and his soul as the way for human reason to know God/Christ and perceive ultimate reality. Eve's submission also denotes the male's leading role in the exercise of man's free will to come in touch with his soul and the divine reason residing in it. The soul admits that she can't exist without man's presence simply because they are one, the former being the essence of the latter. Furthermore, Eve's words stress the idea that reality is mental. Eve says that she will experience the corrupt world in the high mental state only if she is with Adam, implying that man's relationship with the Divine is not spatial but qualitative.

The end of Paradise Lost consists of these lines, "They hand in hand with wand'ring steps and slow,/ Through Eden took their solitary way" (PL, 12:648-649) (Milton, 1674/1993, p. 301). Melancholy permeates the last lines of Paradise Lost that should not be negatively perceived because they serve the Felix culpa theme that Milton's epic revolves around. Humanity must seriously contemplate its lost high mental state and persist in renewing its relationship with God. Milton ends his poem with hope. Even after his fall, man can restore his relationship with God. In the last scene, Adam and Eve preserve their love. Preserving the loving communication with his soul, man makes himself ready to get to know God. The solidarity of Adam (man) and Eve (his soul) endows him with the strength and the will to take the long, challenging, and private path of contemplation toward the restoration of his immortality. Thus, Milton ends Paradise Lost with the optimistic message that man can experience the high mental state within the world of corruption, depending upon which senses-physical or spiritual—he employs.

In Paradise Lost, human reason in the fourth level (the highest mental state) is mirrored in the New Adam (Christ) and the Second Eve (Mary) imageries, humanity enlightened by the Holy Spirit that participates in the eternal and infinite realm. Humanity's pure reason in the fourth level is based on love and creativity. Milton identifies Eve with Mary (the Second Eve), who shares the same attributes with Eve in the high mental state (human reason in the third level). In Book 5:443-450, and Book 8:40-46 and 8:500-507, Eve's innocence in physical terms mirrors pure love, identified 
by Hildegard of Bingen as Caritas, God's virtue residing in the ideal man (the image of God). Other passages that present Eve as a personification of divine virtue and allude to Mary (the Second Eve) are in Book 9, where Milton calls unfallen Eve "the virgin majesty, as one who loves" (PL, 9:270-271) (Milton, 1674/1993, p. 205) and Adam addresses her "Daughter of God and man, immortal Eve,/ For such thou art, from sin and blame entire" (PL, 9:291-292) (Milton, 1993, p. 205).

Other passages where Milton uses Eve's and Mary's physical virginity as an analogical language for humanity's spiritual innocence (pure reason) are the following:"[...] No veil/ She needed, virtue-proof, no thought infirm/Altered her cheek. On whom the angel 'Hail'/ Bestowed, the holy salutation used/ Long after to blest Mary, second Eve" (PL, 5:383-387) (Milton, 1674/1993, p. 123) and "The Great deliverance by her seed to come/ (For by the Woman's Seed) on all mankind" (PL, 12:600-601) (Milton, 1674/1993, p. 300). Mary as the Second Eve is also the feminine part of Christ (His human nature); ${ }^{9}$ through Mary, Christ as fully God unites with and elevates humanity. That is, Mary is the fully human nature of Christ (New Adam). According to Hildegard of Bingen's teachings, God's plan is man's and woman's union and synergy to "allow the image of God to become visible in myriad reflections, corresponding to all the unborn generations still in the womb. Thus woman is both the complement of man and the primordial mother" (Newman, 1997, p. 97). Like a mother, Eve provides all humanity the garment of flesh defined by variety (Newman, 1997, pp. 96-7), and her artistic handiwork manifests the feminine quality of creative imagination. As the loving mother and creative imagination, Eve reveals that man comes from her spiritually and physically.

Finally, every man's poetic genius, which finds expression through the arts and sciences within the physical world, manifests a perfected human reason through the

9 Within the context of Hildegard of Bingen's theology of the feminine, Mary is the feminine side/emanation of God and thus, the femimine portion of Christ. Furthermore, like the Incarnate Word (Christ) is the New Adam, Mary is the New Eve, the Incarnate virtues of God, Sapientia (Reason/Creative imagination) and Caritas (Love) (Newman, 1997, pp. 158, 165-6, 171). Like Hildgard of Bingen, in "Praises of The Virtues With Which The Most Holy Virgin Was Adorned And Which Should Adorn The Holy Soul," Francis of Assisi views Mary as the physical manifestation of God's emanation: "Hail, Queen Wisdom, God save thee with thy holy sister pure Simplicity./ Hail, Lady holy Poverty, God save thee with thy holy sister Humility./ Hail, Lady holy Charity, God save thee with thy sister, holy Obedience./ Hail, all you holy virtues, may God save you, he from whom you come and are derived" (Petry, 2006, p. 122). Francis of Assisi also shares Hildgard's approach to Mary as the mother of Christ/New Adam - "Hail, palace of Christ; hail, tabernacle of Christ, hail, Mother of Christ!" (Petry, 2006, p. 123) —and as the Holy Spirit that activates (and is) the soul of the New Church/the bride of Christ-"Hail to you, holy virtues, who by means of grace and the illumination of the Holy Ghost are infused in the hearts of the faithful [...]" (Petry, 2006, p. 123). 
union between man and Logos in the highest mental state..$^{10}$ In Paradise Lost, Book 1's lengthy proem, Milton, the poet-prophet, prays to the divinity of art, the Holy Spirit. Milton shows his readers that the natural man can achieve perfection and access the supranatural world/the ultimate reality through his role as a poet, using his creative imagination/spiritual senses/divine reason in him. Besides merely following the standards of the composition of an epic poem, Milton purposely alludes to Kalliope (the muse of epic poetry) when he invokes the Holy Spirit. He stresses the main attribute of the Holy Spirit (Logos/divine reason), creative imagination. Kalliope is a female deity. Similarly, the Holy Spirit is the feminine aspect of the Divine. Associating Kalliope with the Holy Spirit, Milton highlights the fertility of Logos: "Sing Heav'nly Muse" (PL, 1:6) (Milton, $1674 / 1993$, p. 8). Milton desires to expand the force of his creativity to a degree not known to the natural man, asking the Holy Spirit to guide him through the composition of a poem that will materialize "Things unattempted yet in prose or rhyme" ( $P L, 1: 15)$ (Milton, 1674/1993, p. 8).

Milton is the poet who wants to employ his artistic talent, realizing that this will happen if he unites with the Logos of God in the highest mental state. Milton pleads, "[...] What in me is dark/ Illumine, what is low raise and support;/ That to the highth of this great argument/ I may assert Eternal Providence,/ And justify the ways of God to men" (PL, 1:22-26) (Milton, 1674/1993, p. 9). He invokes his muse, the Holy Spirit, in complete humility, acknowledging his knowing nothing and surrendering his self/ego to the Divine's love and reason. Embracing God's will as his own will, Milton strengthens the divine reason in him. Thus, he becomes the communication vessel between God and his fellowmen, who have surrendered themselves to the natural reason (the eternal death) by becoming selfhood's (Satan's) victims.

10 In "Of Reformation in England and the Causes that Hitherto Have Hindered It," talking about the corruption of the religious elite dating back to Constantine's time, Milton refers to Dante, Petrarch, Ariosto of Ferrara, and Chaucer, who, as true Christians and carriers of the Divine message, have criticized the institution of the Church as the Antichrist (Milton, 1641/1847, p. 12). These four Catholic men lived during the late Middle Ages/Renaissance-the time Catholic mystics focused on man's perfection (completion of man's union with Christ) that is, man's ascendency to the highest mental state, human reason in the fourth level. Their connecting bond is the full practice of their poetic genius/creative imagination - "the quickening power of the Spirit" within them (Milton, 1641/1847, p. 2), "the intellectual ray which God hath planted in us [...] an extraordinary effusion of God's Spirit upon every age and sex, attributing to all men" (Milton, 1641/1847, p. 15). Referring to poets as role models of virtuous Christians, Milton acknowledges their creativity as the divine reason in them. 


\section{Conclusion}

For Milton, natural reason, synonymous with the senses and finite self-centered existence, traps humanity in the prison of a distorted reality produced in the first level (the lowest mental state) and the second level (the low mental state). Milton repudiates false reason in Paradise Lost by creating imageries of restrainment, suffering, physical ugliness, erotic pervasion, and power relationships. He advocates that love and creativity are the foundations of pure human reason. Man transcends the finite world through the inward expansion of his senses by activating the affections (love) in the third level of human reason (the high mental state) and the faculty of creativity in the fourth level of human reason (the highest mental state), both of which are depicted in Paradise Lost in imageries of abundance physical beauty, fertility, and freshness. Love (the high mental state) and creativity (the highest mental state) guide human reason to surpass its secular/physical boundaries and attain a spiritual nature since the divine attributes are love and creativity (Logos). Therefore, human reason becomes the spiritual bond between man and God, sealing humanity's eternal and infinite existence.

The preservation of a pure human reason through the activation of human love in the high mental state is reflected in a dual union: the love union between a man and his soul (self-knowledge) and the love union between man and Logos (man's rejection of his ego and voluntary submission to God, Who is Love and Creativity). In the highest mental state, being united both with his soul and Logos, man becomes Christlike. He fully activates his poetic genius motivated by his love for his ideal self, fellowmen, and God/the Truth. Inspired by Logos, as the creator of Paradise Lost, Milton becomes the role model of the man whose reason has reached the fourth level. He has a clear, comprehensive, and deep understanding of reality through the exercise of pure reason. Paradise Lost is a characteristic example of seventeenth-century amillennialist Millenarian literature. The redemptive qualities of the mental faculty of reason for humanity are the central theme of Milton's poem, echoing the spirit of the age. Milton stands among the most influential seventeenth-century literary men whose appraisal of human reason foreshadows the reign of reason in eighteenth-century English society, the beginnings of the modern era. Paradise Lost challenges the a priori definition of reason as the mental faculty that enables man to perceive reality based on the senses. Thus, among many other seventeenth-century poetical works, Milton's poetry encourages new readings of eighteenth-century literature based on the alternative definition of reason he advocates. 
In the early nineteenth century, the Romantics hoped for the revival of the Miltonic vision in an era of the revival of millennial expectations. In "London 1802,"Wordsworth compares his contemporary "selfish" (line 6) (Milton, 1807, p. 548) Englishmen to "stagnant waters" (line 3) (Milton, 1807, p. 548). He wishes Milton were alive to enlighten his fellowmen "like a star spiritually and dwelt apart" (line 9) (Milton, 1807, p. 548) and to stir them like a"sea" (line 10) (Milton, 1807, p. 549). For Wordsworth, Milton is a godly man whose poetry is "Pure as the naked heavens, majestic, free" (line 11) (Milton, 1807, p. 549). Thus, future studies may occur within a philosophical context, reconsidering the meaning of reason for and challenging its rejection by the Romantics. Also, future studies may take place within a rhetorical, religious, or sociopolitical context, examining the factors that reinforced the Romantics to use a secular diction to spread the amillennial Miltonic vision in their times.

Paradise Lost is characterized by spiritual universality above its value as Christian and English literary work. In “Lecture X: Donne, Dante, Milton, Paradise Lost," Coleridge points out:

The superiority of the 'Paradise Lost' is obvious in this respect, that the interest transcends the limits of a nation. But we do not generally dwell on this excellence of the 'Paradise Lost', because it seems attributable to Christianity itself;--yet in fact the interest is wider than Christendom, and comprehends the Jewish and Mohammedan worlds;--nay, still further, inasmuch as it represents the origin of evil, and the combat of evil and good, it contains matter of deep interest to all mankind, as forming the basis of all religion, and the true occasion of all philosophy whatsoever. (Coleridge, 1818/1836)

Milton's Paradise Lost's value lies in explaining good and evil, both associated with the mental faculty of reason. Milton associates evil with man's mental fall. Evil is man's ego mirrored in the exclusive use of natural reason towards his perception of the Truth. For Milton, good refers to the intimate relationship of man with his own soul and God. It is the proper use of reason, the assistance of the senses by love and creative imagination, through which human consciousness's expansion becomes infinite and eternal. Thus, the value of Milton's Paradise Lost is both religious and philosophical because it attempts to answer perennial existential questions of humanity related to human essence, human happiness, and human immortality. 
Peer-review: Externally peer-reviewed.

Conflict of Interest: The author has no conflict of interest to declare.

Grant Support: The author declared that this study has received no financial support.

Hakem Değerlendirmesi: Dış bağımsız.

Çıkar Çatışması: Yazar çıkar çatışması bildirmemiştir.

Finansal Destek: Yazar bu çalışma için finansal destek almadığını beyan etmiştir.

\section{References}

\section{Primary Sources}

Anselm, Canterbury of. (1076/2008). Monologion. In B. Davies and G. R. Evans (Eds.).

Anselm of Canterbury/The major works including monologion, proslogion, and why God became man (pp. 5-81). Oxford: Oxford University Press.

---. (2008). On free will. In B. Davies and G. R. Evans (Eds.), Anselm of Canterbury/The major works including monologion, proslogion, and why God became man (pp. 175-192). Oxford: Oxford University Press.

Athanasius, Alexandria of. On the incarnation of the Word. https://ccel.org/ccel/a/athanasius/incarnation/cache/ incarnation.txt

Augustine, Hippo of. (1871). The city of God, volume I. (M. Dods, Trans.), The works of Aurelius Augustine, Bishop of Hippo/A new translation. https://www.gutenberg.org/files/45304/45304-h/45304-h.htm

Behmen, J. (1901). Dialogues on the supersensual life (B. Holland, Ed.). London: Methuen \& co. https://www. gutenberg.org/files/33742/33742-h/33742-h.htm

Catherine, Siena of. (1370/1896). A treatise of divine providence. (A. Thorold,Trans.), The dialogue of the seraphic virgin Catherine of Siena (pp. 19-36). London: Kegan Paul, Trench,Trubner \& co., Ltd. https://archive.org/ stream/seraphicvirginca00cathuoft/seraphicvirginca00cathuoft_djvu.txt

Coleridge, S. T. (1836). The Literary Remains of Samuel Taylor Coleridge, vol.1 (Henry Nelson Coleridge, Ed.). http:// www.gutenberg.org/cache/epub/8488/pg8488.txt

Francis, Assisi of. (2006). Praises of the virtues with which the most holy virgin was adorned and which should adorn the holy soul. In R. C. Petry (Ed.), Late medieval mysticism (pp. 122-3). Louisville, Kentucky: Westminster John Knox Press.

Homer. (1791). The lliad of Homer translated into English blank verse (W. Cowper, Trans. \& R. Southey, Ed.). New York: D. Appleton \& Co. http://www.gutenberg.org/cache/epub/16452/pg16452.txt

Milton, J. (1641/1847). Of reformation in England, and the causes that hitherto have hindered it. In two books. In J. W. Moore (Ed.), The prose works of John Milton: With a biographical introduction by Rufus Wilmot Griswold, vol. I (pp. 1-34). Philadelphia: King \& Baird. http://oll.libertyfund.org/titles/1209 
---. (1674/1993). Paradise lost. In S. Elledge (Ed.), Paradise lost: An authoritative text, backgrounds and sources/John Milton (pp. 7-301). USA: W. W. Norton \& Company.

Plato. (1892). Symposium. In B. Jowett (Ed. \& Trans.), The dialogues of Plato, vol. 1 (pp. 172-223). London: Oxford University Press. https://oll.libertyfund.org/title/jowett-thedialoguesof-plato-vol-1

Rolle, Richard. (1918). The mending of life. In W. H. Hulme (Ed.), Richard Rolle of Hampole's mending of life, from the fifteenth century Worcester cathedral manuscript F. 172 (pp. 29-58). Cleveland, Ohio: Western Reserve University Press. https://archive.org/stream/RichardRolleOfHampolesMendingOfLifeFromTheFifteenthCentury/richard_ rolle_mending_Rolle_djvu.txt

Theologia Germanica. (1893). S. Winkworth, Trans. \& Dr. Peiffer Ed. Golden Treasure Series. https://www.ccel.org/ ccel/anonymous/theologia.html

Sophocles. (1974). King Oedipus. (E. F. Watling, Trans.), The Theban plays: King Oedipus/Oedipus at Colonus/ Antigone (pp. 25-68). London: Penguin Books.

Wordsworth, W. (1807/2012). London 1802. In W. Duncan (Ed.), Romanticism: An anthology (pp. 548-9). UK: John Wiley \& Sons, Ltd.

\section{Secondary Sources}

Asiatidou, K. (2020). The presence of the 'Zohar' in Milton's 'paradise lost': Intertextuality and orthodox Christian rhetoric. In Z. Antakyalıoğlu et al. (Eds.) English studies in the 21st century (pp. 1-15). UK: Cambridge Scholars Publishing.

Black, J. (Ed.). (2002). World history: From prehistoric times to the present day. UK: Parragon Publishing.

Brodey, K., \& Malgaretti, F. (2002). Focus on English and American literature. Milan, IT: Modern Languages.

Burke, C. (2012). St. Augustine: A view on marriage and sexuality in today's world. Angelicum, 89(2), $377-403$. https://www.jstor.org/stable/44618600

Chamberas, P. A. (2004). Foreword. In G. Papadopoulos, At the end of time: The eschatological expectations of the church (pp. vii-xii). Brookline, MA: Holy Cross Orthodox Press.

Colie, R. L. (1959). Spinoza and the early English deists. Journal of the history of ideas, 20(1), 23-46. https://www. jstor.org/stable/2707965

Collett, J. H. (1970). Milton's use of Classical mythology in "paradise lost." PMLA, 85(1), 88-96. https://www.jstor. org/stable/1261434

Damon, S. F. (1988). A Blake dictionary: The ideas and symbols of William Blake. USA: University Press of New England.

Dockrill, D. W. (1997). The heritage of Patristic Platonism in seventeenth-century English philosophical theology. In G. A. Rogers et al. (Eds.) The Cambridge Platonists in philosophical context: Politics, metaphysics and religion (pp. 55-77). Springer Science \& Business Media.

Duncan, J. E. (1957). Milton's four-in-one hell. Huntington Library Quarterly, 20(2), 127-136. http://www.jstor.org/ stable/3816365 
Grene, M. (1999). Descartes and skepticism. The Review of Metaphysics, 52(3), 553-571. https://www.jstor.org/ stable/20131190

Grant, M., \& Hazel, J. (2006). Who's who in classical mythology. New York, NY: Routledge Kerenyi, C. (2002).The gods of the Greeks. USA: Thames \& Hudson Ltd.

Kim, J. J. (2008). Archbishop John Tillotson and the 17th century Latitudinarian defense of Christianity, Part I. TTJ, 11(1), 130-146. http://www.ttgst.ac.kr/upload/ttgst_resources13/20124-237.pdf

Lefokovitz, L. H. (2011). The genesis of gender transgression. The Jewish Quarterly Review, 101(3), $408-419$. https://www.jstor.org/stable/41300146

Low, A. (1970). The image of the tower in paradise lost. Studies in English Literature, 1500-1900, 10(1), $171-181$. https://www.jstor.org/stable/449702

Myers, B. (2004). The theology of freedom in paradise lost. James Cook University, Queensland, AU.

Newman, B. (1997). Sister of wisdom: St. Hildegard's theology of the feminine. Berkeley and Los Angeles, CA: University of California Press.

Sargent, L. T. (1989). Millennium and revolution: Two themes in seventeenth century British utopianism. Utopian Studies, 2, 38-49. http://www.jstor.org/stable/20718904

Thompson, E. N. S. (1921). Mysticism in seventeenth century English literature. Studies in Philology, 18(2), 170231. https://www.jstor.org/stable/4171790

Tredennick, L. (2011). Exteriority in Milton and Puritan life writing. Studies in English Literature, 1500-1900, 51(1), 159-179. https://www.jstor.org/stable/23028097

Ward, G. (2010). How literature resists secularity. Literature and theology, 24(1), 73-88. http://www.jstor.org/ stable/23927407

Yam, C. Y., \& Dupont, A. (2012). A mind-centered approach of imago dei a dynamic construction in Augustine's de Trinitate XIV. Augustiniana 62(1/2), 7-43. https://www.jstor.org/stable/44993092 
